Terbit online pada laman web jurnal : http://e-journal.sastra-unes.com/index.php/JIPS

\begin{tabular}{|c|c|c|}
\hline \multirow{2}{*}{ Fakultas Sastra } & \multicolumn{2}{|c|}{$\begin{array}{c}\text { JURNAL JIPS } \\
\text { (Jurnal Ilmiah Pendidikan Scholastic) }\end{array}$} \\
\hline & $\begin{array}{c}\text { Vol.5No. } 1 \\
\text { ISSN : } 2579-5449 \\
\text { (media cetak) }\end{array}$ & $\begin{array}{c}\text { E-ISSN : } \\
2597-6540 \\
\text { (media online) }\end{array}$ \\
\hline
\end{tabular}

\title{
PENGGUNAAN TEKNIK OBJEK LANGSUNG DALAM MENULIS KARANGAN DESKRIPSI
}

\author{
Susanti Marisya \\ Universitas Ekasakti \\ Dosen Program Studi Pendidikan Bahasa dan Sastra Indonesia
}

\begin{abstract}
Keterampilan menulis deskripsi merupakan sebuah keterampilan yang wajib diajarkan dalam pembelajaran bahasa Indonesia karena tecantum dalam silabus kelas X Sekolah Menengah Atas. Beberapa bukti yang mengatakan bahwa keterampilan menulis deskripsi siswa masih rendah terlihat dalam penelitian yang dilakukan oleh Purbania, dkk tahun 2020 dalam jurnal bahasa, sastra, dan pengajaran vol 8 no 1. Berdasarkan penelitian yang telah dilakukan diketahui bahwa kemampuan menulis deskripsi siswa belum baik dan tergolong kategori cukup dengan rentang nilai 61-75. Nilai tersebut belum memenuhi standar KKM Adapun kesulitan-kesulitan yang dihadapi siswa dalam pembelajaran menulis deskripsi, yaitu (1) siswa sulit mengembangkan ide dalam menulis deskripsi, (2) sulit mengembangkan kalimat, (3) siswa sulit menentukan ejaan yang baik dan benar dan sulit berkonsentrasi.

Salah satu upaya untuk mengatasi permasalahan siswa tersebut, guru seharusnya menerapkan suatu teknik dalam pembelajaran sehingga pembelajaran lebih efektif, inovatif dan memberikan stimulus kepada siswa untuk mengembangkan ide dalam menulis sesuai dengan objek yang dilihat. artikel ini bertujuan untuk menjelaskan mengenai penggunaan teknik objek langsung dalam keterampilan menulis deskripsi siswa.
\end{abstract}

Keywords: Menulis Deskripsi dan Teknik Objek Langsung

(C) 2021Jurnal JIPS

\section{INTRODUCTION}

Bahasa berfungsi sebagai alat komunikasi. Pembelajaran bahasa dan sastra Indonesia diarahkan agar siswa terampil berkomunikasi, baik lisan maupun tertulis. Pembelajaran bahasa, selain untuk meningkatkan keterampilan berbahasa, juga untuk meningkatkan kemampuan berpikir, mengungkapkan gagasan, perasaan, pendapat, persetujuan, keinginan, penyampaian informasi tentang suatu peristiwa dan kemampuan memperluas wawasan. Pembelajaran bahasa dan sastra Indonesia haruslah diarahkan pada hakikat bahasa dan sastra Indonesia sebagai alat komunikasi. Sebagaimana diketahui sekarang ini orientasi pembelajaran bahasa berubah dari penekanan pada pembelajaran aspek bentuk ke pembelajaran yang menekankan pada aspek fungsi.

Salah satu aspek yang harus dikuasai dalam pembelajaran bahasa adalah menulis. menulis merupakan suatu keterampilan berbahasa yang dipergunakan untuk berkomunikasi secara tidak langsung. Menulis adalah suatu kegiatan yang aktif dan produktif serta memerlukan cara berpikir yang teratur yang diungkapkan dalam bahasa tulis. Semi (2003) menyatakan bahwa menulis itu tidak lain dari upaya memindahkan bahasa lisan ke dalam tulisan, dengan menggunakan lambang-lambang grafem. Namun, seringkali pula menulis itu dianggap sebagai suatu keterampilan berbahasa

Jurnal JIPS (Jurnal Ilmiah Pendidikan Scholastic) Vol. 5 No. 1 (2021) ISSN : 2579-5449

This work is licensed under a Creative Commons Attribution-NonCommercial 4.0 International License. 
yang sulit, karena menulis dikaitkan dengan seni dan kiat. Menulis juga dipengaruhi oleh keterampilan produktif lainnya, seperti aspek berbicara maupun keterampilan reseptif yaitu aspek membaca dan menyimak serta pemahaman kosakata, diksi, keefektifan kalimat, penggunaan ejaan, dan tanda baca. Pemahaman berbagai jenis karangan serta pemahaman berbagai jenis paragraf dan pengembangannya.

Sesuai dengan standar isi kurikulum 2013, kemampuan menulis yang harus dikuasai siswa, yaitu menulis tulisan argumentasi, ringkasan, surat pribadi, surat dinas, deskripsi, narasi, dan eksposisi. Salah satu materi pembelajaran yang harus diajarkan pada siswa adalah pembelajaran menulis deskripsi. Pembelajaran menulis deskripsi merupakan hal yang diteliti dalam penelitian ini. Pembelajaran menulis deskripsi tercantum dalam kurikulum 2013 kelas X. Suparno (2008:4-6) mengatakan deskripsi adalah suatu bentuk karangan yang melukiskan sesuatu sesuai dengan keadaan yang sebenarnya sehingga pembaca dapat mencitrai (melihat, mendengar, mencium dan merasakan) apa yang dilukiskan sesuai dengan citra penulisnya. Pembaca deskripsi ikut mencitrai objek yang digambarkan atau dilukiskan oleh penulis.

Berdasarkan penelitian yang dilakukan oleh Purbania, dkk tahun 2020 (dalam jurnal Basastra vol 8 no 1) dapat diketahui bahwa pada pembelajaran menulis khususnya pembelajaran menulis deskripsi terdapat berbagai permasalahan yang dialami siswa. Siswa merasa kesulitan dalam mengembang ide dalam menulis terlihat siswa kebanyakan melamun dan tidak mampu menyelesaikan tulisan dengan tepat waktu. Untuk itu, diharapkan agar siswa memiliki pengetahuan sehingga dapat menuangkan ide dan gagasan dalam kalimat dengan baik sehingga tujuan dari deskripsi dapat tercapai. Siswa pun juga sulit untuk mengemabngkan kalimat karena masih terbatasnya penguasaan dan pilihan kata dalam menulis deskripsi. Hal tersebut menyebabkan banyak cerita yang kurang tergambarkan dengan jelas dan kurangnya pengembangan ide dan pikiran dalam bentuk menulis deskripsi. Selain itu, siswa kurang memahami ejaan yang baik dan benar dalam menulis sehingga tulisan yang dihasilkan kurang sesuai dengan kaidah Ejaan Bahasa Indonesia yang baik dan benar. Kurang fokus dan konsentrasinya siswa dalam pembelajaran menulis deskripsi juga merupakan kendala karena metode pembelajaran yang kurang bevariasi dan menarik bagi siswa.

Sebagai seorang pendidik dan pengembang pengetahuan, guru bahasa Indonesia mempunyai tanggungjawab untuk memperbaiki dan mengatasi permasalahan yang terjadi sehingga kemampuan menulis siswa khususnya menulis deskripsi menjadi lebih baik dan sesuai dengan tujuan yang diharapkan. Salah satu alternatif yang digunakan adalah dengan memberikan sebuah teknik pembelajaran yang menarik bagi siswa yaitu dengan menggunakan teknik objek langsung. Teknik ini diharapkan dapat mengubah persepsi siswa selama ini yang menganggap pembelajaran menulis membosankan menjadi pembelajaran yang menarik dan menyenangkan.

Berdasarkan fenomena yang telah dipaparkan, penulis ingin menjelaskan mengenai penggunaan Teknik Objek Langsung dalam Keterampilan Menulis Deskripsi Siswa Kelas X. Adapun tujuan dari tulisan ini untuk menjelaskan penggunaan teknik objek langsung dalam pembelajaran keterampilan menulis deskripsi siswa kelas $\mathrm{X}$.

\section{RESEARCH METHOD}

Metode Penelitian yang dilakukan adalah studi pustaka dengan menggunakan penelitian kepustakaan. Pada penelitian ini dasar yang dilakukan untuk melakukan penelitian ini yaitu; penelitian ini secara langsung dihadapkan dengan data, fakta, dan tes teks yang telah ada, bukan memperoleh data di lapangan atau melalui saksi mata berupa kejadian, peneliti hanya berhadapan langsung dengan sumber yang sudah ada di perpustakaan atau data bersifat siap pakai, serta data data sekunder yang digunakan seperti jurnal, arikel, dan hasil penelitian (Snyder dalam Pringar, jurnal ITDEU, 2020:319). Mendes, Wohlin, Felizardo, \& Kalinowski, (2020) mengungkapkan prosedur dalam penelitian kepustakaan dilakukan melalui 
kajian literatur dan penggabungan topik yang relevan dengan penelitian kemuadian menganalisis topik tersebut. Penelitian studi pustaka ini memanfaatkan sumber berupa jurnal, buku, kamus, dokumen, majalah dan sumber lain tanpa melakukan penelitian ke lapangan.

Peneliti mengumpulkan beberapa jurnal yang relevan dengan penelitian ini yaitu mengenai penggunaan teknik objek langsung dalam pembelajaran menulis deskripsi, kemudian melakukan analisis data menggunakan analisis kualitatif deskriptif melalui studi pustaka, hasil dari analisis tersebut didapat berupa data deskriptif yang diamati dari hasil penelitian yang dilakukan oleh peneliti sebelumnya. Menurut Miles dan Huberman, 2014, ada pun tahapan dalam penelitian ini adalah:

1. Tahap mengumpulkan data, merupakan proses mengumpulkan data yang diperoleh dari jurnal yang relevan dengan penelitian teknik objek langsung dalam pembelajran menulis deskripsi sehinggaa peneliti memperoleh informasi dan jawaban terhadap rumusan masalah penelitian.

\section{RESULTS AND DISCUSSION}

Berdasarkan analisis data yang dilakukan maka terdapat beberapa telaah terkait dengan jurnal yang relevan dengan penelitian yang dilakukan peneliti yaitu sebagai berikut:

Pertama, Penelitian yang dilakukan oleh Lis Supriyati Tahun 2013 dalam jurnal pendidikan bahasa Indonesia Vol 1, No 3 dengan judul Peningkatan Kemampuan Menulis Paragraf Deskripsi dengan Teknik Objek Langsung pada Siswa Kelas VIII SMP Negeri Karaanyam Kabupaten Kebumen TA 2012/ 2013, inti pembahasan dalam penelitian ini, sikap siswa mengalami perubahan positif (siswa memperhatikan dan merespons dengan antusias (bertanya, menanggapi, dan membuat catatan), siswa berpartisipasi secara aktif dalam kegiatan diskusi kelompok, siswa merespons positif (senang) terhadap pembelajaran dengan teknik objek langsung, siswa aktif menjawab dan selalu bertanya apabila menemukan kesulitan, siswa menulis paragraf deskripsi dengan sikap yang baik) pada siklus I sekor rata-rata $62,8 \%$ dan pada siklus II skorrata-rata $89,4 \%$. Dengan demikian, perubahan siswa yang bersikap positif
2. Tahap reduksi data, merupakan teknik menganalisis data yang mendalami, menggolongkan, mengarahkan, memisahkan data yang tidak dibutuhkan, dan mengorganisasikan data sedemikian rupa agar memperoleh kesimpulan akhir dan diverifikasi. Mengklasifikasikan jurnal-jurnal yang berhubung dengan dengan teknik objek langsung dalam pembelajaran menulis deskripsi.

3. Tahap menyajikan data, mengkaji setiap hal yang bermanfaat bagi penelitian dan menarik kesimpulan serta pengambilan tindakan dari data yang memungkinkan. Mendata data sekunder berupa jurnal mengenai teknik objek langsung dalam pembelajaran menulis deskripsi sehingga memperoleh beberapa kesimpulan umum dari jurnal yang diteliti.

Tahap menarik kesimpulan/verifikasi, merupakan proses menyimpulkan hasil penelitian yang telah ditemukan mengenai teknik objek langsung dalam pembelajaran menulis deskripsi.

semakin bertambah dari siklus I ke siklus II sebesar 26,6\%. Perolehan skor berdasarkan kriteria sangat baik dan baik meningkat dari prasiklus sampai dengan siklus II. Pada kriteria kurang dan sangat kurang mengalami penurunan dari prasiklus sampai dengaan siklus II. Hal ini menunjukkan adanya peningkatan kemampuan menulis paragraf deskripsi dengan teknik objek langsung. Berdasarkan pembahasan tersebut dapat disimpulkan bahwa setelah mengikuti pembelajaran menulis paragraf deskripsi dengan teknik objek langsung, pada siklus I dan siklus II perubahan sikap positif (bertanya, menanggapi, dan membuat catatan), siswa berpartisipasi secara aktif dalam kegiatan diskusi kelompok, siswa merespons positif (senang) terhadap pembelajaran dengan teknik objek langsung, siswa aktif menjawab dan selalu bertanya apabila menemukan kesulitan, siswa menulis paragraf deskripsi dengan sikap yang baik) semakin bertambah. Selain itu, peningkatan juga terlihat dalam nilai siswa.

Kedua, penelitian yang dilakukan oleh Yuli Budi Riwati dan Retno Danu Rusmawati 
pada tahun 2014 dalam jurnal Basastra No 1, Vol 1 dengan judul Peningkatan Keterampilan Menulis Deskripsi Mahasiswa dengan Teknik Objek Langsung Melalui Model Pembelajaran Risma. Inti pembahasan dalam penelitian ini adalah hasil belajar siswa menulis deskripsi dengan menggunakan teknik objek langsung menampakkan peningkatan ke arah yang lebih baik karena rata-rata tiap siklus menunjukkan hasil yang baik. Hal tersebut dibuktikan dengan rata-rata nilai mahasiswa $75 \mathrm{ke}$ atas. Hasil belajar tiap siklus juga mengalami peningkatan dan tingkat ketuntasan dikategorikan dalam kategori baik. Berdasarkan pembahasan tersebut dapat disimpulkan bahwa pembelajaran menulis deskripsi dengan menggunakan teknik objek langsung dapat meningkatkan kualitas dan hasil belajar siswa karena teknik ini dapat mengatasi kejenuhan mahasiswa dalam proses pembelajaran terutama dalam menulis deskripsi.

Ketiga, penelitian yang dilakukan oleh Azizah Malika Yunitawati, Abdul Ngalim, dan Atiqa Sabardila, tahun 2010 dalam jurnal penelitian Humaniora Vol 11, No 1 dengan judul Peningkatan Keterampilan Menulis Karangan Deskripsi dengan Metode Field Trip pada Siswa Kelas V B SDN Gemolong 1 TA 2009/2010. Inti pembahasan dalam penelitian ini yaitu Pemilihan metode objek langsung dengan beberapa pertimbangan yaitu. Pertama, model pembelajaran yang menggunakan metode field trip adalah suatu strategi pembelajaran yang memanfaatkan lingkungan sebagai sumber dan sarana belajar. Kedua, apabila siswa diajak berkunjung ke lingkungan sekitar siswa dapat melakukan observasi suatu objek yang ada secara langsung. Melalui penggambaran secara nyata terhadap objek, secara tidak langsung membuat pembelajaran menulis deskripsi akan berjalan lebih efektif karena daya imajinasi siswa dapat berkembang. Berdasarkan nilai yang diperoleh siswa pada siklus I, secara umum dapat disimpulkan bahwa hasil karangan deskripsi yang dihasilkan sudah cukup baik apabila dibandingkan dengan hasil tulisan pada survei awal. Proses pembelajaran menulis yang telah dilaksanakan pada siklus I pada umumnya sudah cukup baik, tetapi belum memuaskan. Hasil tulisan siswa menunjukkan bahwa telah terjadi peningkatan keterampilan menulis siswa. Jika dilihat dari segi isinya, tulisan/karangan siswa pada siklus II ini jauh lebih baik dibanding siklus
I. tindakan pada siklus II ini dikatakan berhasil. Peningkatan terjadi pada beberapa indikator bila dibanding dengan siklus sebelumnya. Berdasarkan pembahasan tersebut dapat disimpulkan bahwa Ada dua simpulan dalam penelitian ini. Pertama, penerapan metode field trip dapat meningkatkan kualitas proses dalam pembelajaran menulis karangan deskripsi. Hal ini ditandai meningkatnya persentase keaktifan. Pada siklus I siswa yang aktif terhadap pembelajaran sebesar $65,38 \%$ atau 17 siswa dari 26 siswa. Pada siklus II siswa yang aktif terhadap pembelajaran sebesar $84,61 \%$ atau 22 siswa dari 26 siswa. Selain meningkatnya persentase keaktifan siswa, meningkatnya kualitas proses dalam pembelajaran menulis karangan deskripsi juga ditandai dengan meningkatnya keterampilan guru dalam mengelola kelas di tiap siklusnya. Kedua, penerapan metode field trip dapat meningkatkan kualitas hasil dalam pembelajaran menulis karangan deskripsi. Hal ini ditandai dengan meningkatnya keterampilan menulis karangan deskripsi siswa dan meningkatnya perolehan nilai menulis karangan deskripsi siswa.

Keempat, penelitian yang dilakukan oleh Juwita Erdaini dan Sri Andayani pada tahun 2018 dalam jurnal Serunai Ilmu Pendidikan No 1, Vol 4 dengan judul Kemampuan Menulis Paragraf Deskripsi Menggunakan Teknik Objek Langsung oleh Siswa Kelas VII MTS Nurul Furqoon Binjai Kab. Binjai Barat TA 2018/ 2019. Inti pembahasan dalam penelitian ini yaitu kemampuan menulis paragraf deskripsi menggunakan teknik objek langsung oleh siswa kelas VII Madrasah Tsanawiyah Nurul Furqoon Binjai Kecamatan Binjai Barat Tahun Pelajaran 2018/2019, dengan skor presentase tingkat penguasaan sebesar 99,99\% dikatagorikan baik sekali. Berdasarkan perhitungan diketahui nilai rata-rata kemampuan menulis paragraf deskripsi menggunakan teknik objek langsung oleh siswa kelas VII Madrasah Tsanawiyah Nurul Furqoon adalah 80 masuk dalam kategori baik. Berdasarkan pembahasan tersebut, dapat disimpulkan bahwa Kemampuan menulis paragraf deskripsi menggunakan teknik objek langsung oleh

siswa kelas VII Madrasah Tsanawiyah Nurul Furqoon Binjai Kecamatan Binjai BaratTahun Pelajaran 2018/2019 dapat dikatagorikan cukup, dengan nilai rata-rata 80 , 
sedangkan tingkat presentasi masing-masing siswa dalam setiap aspek sangat memuaskan.

Berdasarkan telaah jurnal penelitian yang dilakukan oleh beberapa peneliti dapat disimpulkan bahwa penggunaan teknik objek langsung dinilai efektif dalam pembelajaran menulis deskripsi. Selain itu, teknik objek langsung rata-rata dapat meningkatkan hasil belajar siswa dan menambah motivasi siswa dalam pembelajaran menulis deskripsi. Guru melalukan beberapa fase dalam penerapan teknik objek langsung ini diantaranya mengecek persiapan siswa dan memberi penjelasan mengenai tujuan pembelajaran, pada kegiatan inti, guru mengajak siswa untuk melihat dan mengamati objek secara langsung, mengindentifikasi objek-objek yang dilihat, kemudian barulah nanti siswa mengembangkan gagasan terkait dengan objek yang mereka lihat dan mulai menulis deskripsi. Hal itu sesuai dengan pendapat Suyatno 2004:82 bahwa teknik objek langsung bertujuan agar siswa dapat menulis dengan cepat berdasarkan objek yang dilihatnya. Penggunaan teknik ini dilakukan dengan tiga fase yang sangat penting pertama, Guru mengawali dengan penjelasan tentang tujuan dan latar belakang pembelajaran serta mempersiapkan siswa untuk menerima penjelasan guru. Kedua, siswa diajak untuk melihat objek secara langsung. Ketiga, siswa mengindetifikasi objek-objek yang mereka amati, kemudian mengembangkan ide dan mulai menulis dengan runtut. Teknik ini dapat diterapkan pada perorangan atau punkelompok dengan melakukan pengamatan secara langsung. Pengamatan objek secara langsung akan memotivasi siswa dalam belajar khususnya memotivasi untuk menulis karena didukung dengan suasana yang menarik dan menyenangkan bagi siswa.

\section{CONCLUSION}

Berdasarkan analisis data dan pembahasan dapat disimpulkan bahwa hasil tes keterampilan menulis deskripsi siswa yang diajar dengan teknik objek langsung lebih meningkat. Hal tersebut disebabkan karena penggunaan objek langsung memiliki keunggulan seperti, guru memotivasi siswa dengan mengubah susasana pembelajaran menjadi lebih menarik dengan menghadirkan suasana yang nyaman bagi siswa seperti langsung mengajak siswa ke luar ruang kelas untuk belajar menulis deskripsi dengan mengamati objek secara langsung. Selain itu, siswa mampu mengamati benda-benda sekitar secara langsung yang dapat membangkitkan siswa untuk mengembangkan ide dalam menulis. Jadi, apabila teknik objek langsung ini dilakukan dengan langkah-langkah yang benar maka mampu meningkatkan hasil belajar menulis keterampilan menulis deskripsi.

\section{SARAN}

Berdasarkan
dikemukakan di atas maka

mengemukakan saran sebagai berikut. Pertama, guru-guru bahasa Indonesia, khususnya guru bahasa Indonesia agar lebih berupaya meningkatkan latihan menulis deskripsi. Salah satu caranya adalah dengan mengembangkan teknik pembelajaran yang kreatif, inovatif, serta memotivasi siswa seperti dengan menggunakan teknik objek langsung. Kedua, Para siswa hendaknya tidak menganggap bahwa pembelajaran menulis khususnya menulis deskripsi adalah hal yang sulit dan membosankan karena dengan adanya pengetahuan dan keterampilan memudahkan siswa dalam menulis. Menerapkan teknik objek langsung dalam pembelajaran menulis deskripsi siswa menjadi lebih antusias dan memahami penulisan deskripsi. Ketiga, kepada para peneliti selanjutnya agar menggunakan teknik ini secara mendalam dalam meneliti mata pelajaran yang lain . 


\section{Bibliography}

[1]Arikunto, Suharsimi. 2002. Prosedur Penelitian. Jakarta: Rineka Cipta.

[2]Depdiknas. 2005. Kamus Besar Bahasa indonesia Edisi Ke-3. Jakarta: Balai Pustaka.

[3]Erdaini, Juwita dan Sri Andayani. 2018. Kemampuan Menulis Paragraf Deskripsi Menggunakan Teknik Objek Langsung oleh Siswa Kelas VII MTS Nurul Furqoon Binjai Kecamatan Binjai Barat TP 2018/2019."Jurnal Serunai Ilmu Pendidikan". No1, Vol4. https://ejournal.stkipbudidaya.ac.id/index. $\mathrm{php} / \mathrm{ja} /$ article/view/102. Diakses 7 Juni 2021.

[4]Purbania, Basyaroh, dkk. 2020. Kemampuan Menullis Teks Deskripsi Siswa Sekolah Menengah Kejuruan.” Jurnal Bahasa, Sastra, dan Pengajaran". No1, Vol8. https://jurnal.uns.ac.id/Basastra/article/vie w/41963. Diakses 7 Juni 2021.

[5]Purwaningsih. 2004. Karangan Deskripsi. Jakarta: PT Gramedia.

[6]Semi, M. Atar.2003. Menulis Efektif. Padang: Angkasa Raya.

[7]Sudjana, Nana dan Ahmad Rivai.1990. Media Pengajaran. Bandung: Sinar Baru Algesindo

[8]Suparno, dkk. 2008. Keterampilan dalam Menulis. Jakarta: Universitas Terbuka.

[9]Supriyati, Lis. 2013. Peningkatan Kemampuan Menulis Paragraf Deskripsi dengan Teknik Objek Langsung pada Siswa Kelas VIII SMP Negeri 1 Karanggayam Kabupaten Kebumen Tahun Ajaran 2012/ 2013. "Jurnal Pendidikan Bahasa dan Sastra Indonesia” No3 Vol01. http://ejournal.umpwr.ac.id/index.php/sury a-bahtera/article/view/802/772. Diakses tanggal 16 Juni 2021.

[10]Sugiyono. 2006. Metode Penelitian Kuantitatif, Kualitatif, dan $R \& D$. Bandung: Alfabeta.

[11]Suyatno. 2004. Teknik Pembelajaran Bahasa dan Sastra. Surabaya: SIC.

[12]Rusmawati, Retno Danu dan Yuli Budi Riwayati. 2014. Peningkatan Keterampilan Menulis Deskripsi Mahasiswa dengan Teknik Objek Langsung Melalui Model Pembelajaran Risma. "Jurnal Bastra, No1, Vol1, https://karyailmiah.unipasby.ac.id/wpcontent/uploads/2014/08/risma-full.pdf. Diakses tanggal 7 Juni 2021.

[13]Yunitawati, Azizah Malikha, dkk. 2010. Peningkatan Keterampilan Menulis Karangan Deskripsi dengan Metode Field Trip pada Siswa Kelas VB SDN Gemolong 1 TA 2009/2010.” Jurnal Penelitian Humaniora" No1, Vol11. https://publikasiilmiah.ums.ac.id/handle/1 1617/656?show=full. Diakses 6 Juni 2021.

Jurnal JIPS (Jurnal Ilmiah Pendidikan Scholastic) Vol. 5 No. 1 (2021) ISSN : 2579-5449

This work is licensed under a Creative Commons Attribution-NonCommercial 4.0 International License. 